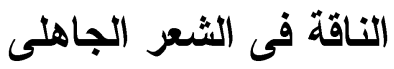

\author{
حمود الاغيثى
}

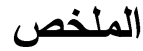

يناقش البحث قضية الناقة التى لم يكن دور ها فى الحياة الجاهلية يقتصر على القى

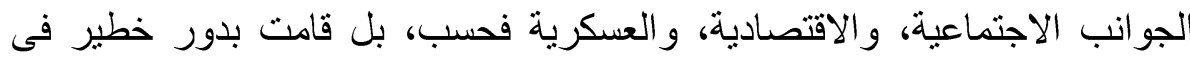

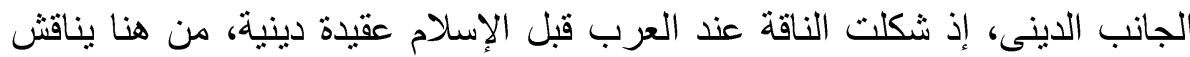
البحث الطقوس العقدية فى الناقة النىى كان يمارسها العرب في الجئ الجاهلية. 


\title{
Convalescents in Jahili poetry
}

\section{Hammood Al-Daghishi}

\begin{abstract}
This research studies the role of convalescents in Jahili( preIslamic) life in the social reconomic military and religious domains the convalescent represented a fundamental religious creed and many rituals performed before the rise of Islam.
\end{abstract}




\section{الناقة في الثعر الجاهلي \\ دراسة في ضوء علم الميثولوجيا}

حمود الاغيشى

ارتبطت الإبل منذ القديم بالإنسان العربي، وكانت علامة بارزة في صحر ائه

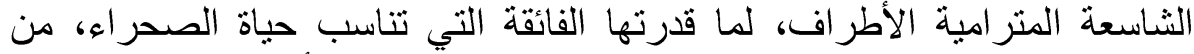

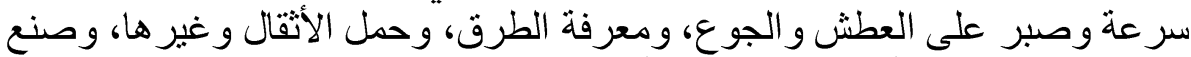

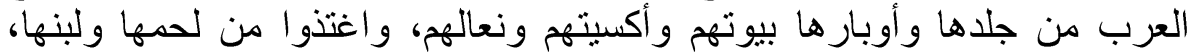

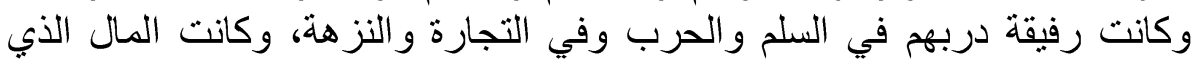

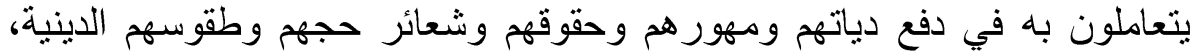

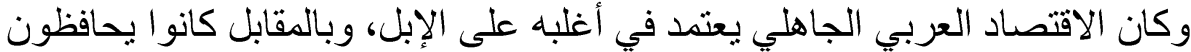

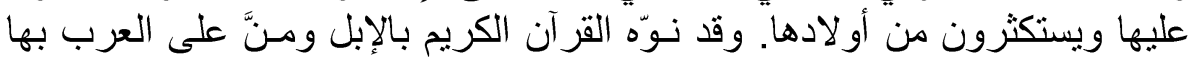

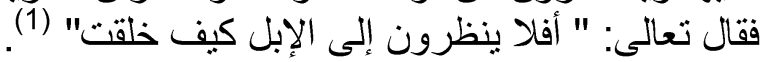
ولم يقتصر دور الناقة في حياة العرب الجاهليين على ذلك فحسب، بل كانت

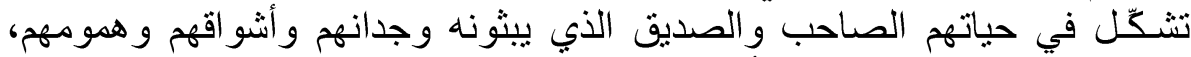
و اتخذوها معادلا موضوعيًا لأحو الهم النفسية وتقلباتهم العاطفية، و وغدت فرداً

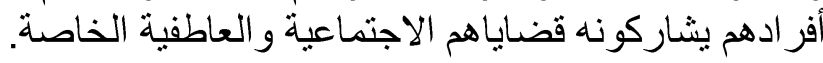
الناقة و الادِّين:

ولعل أخطر دور قامت به الإبل في حياة العرب الجاهلية هو دخولها الحياة

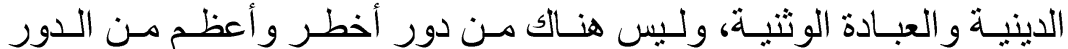

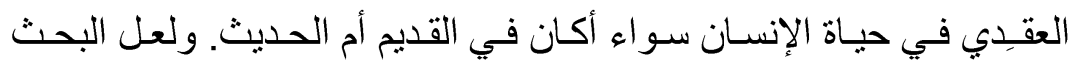

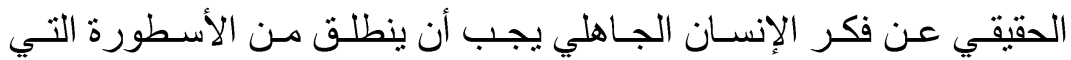

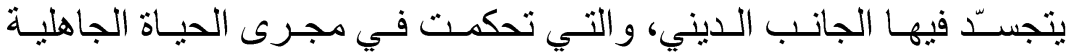

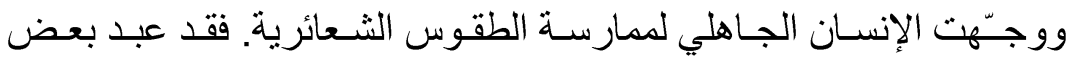

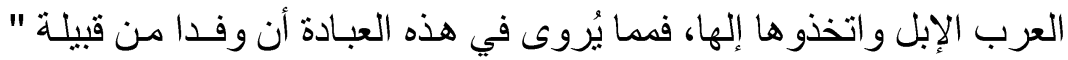

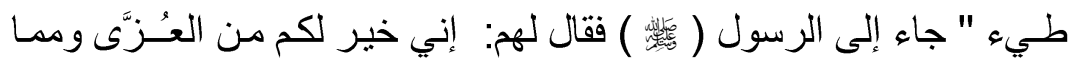

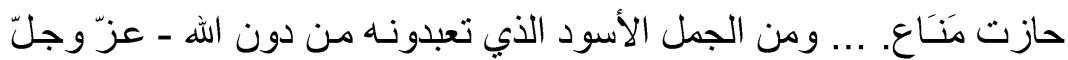


ويبدو من الرواية أن اللون الأسود للجمل كانت له ميزة أسطورية معينة في

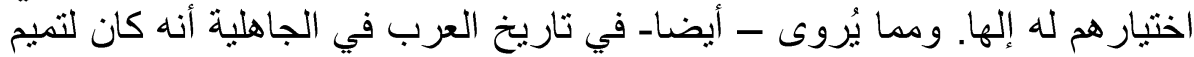

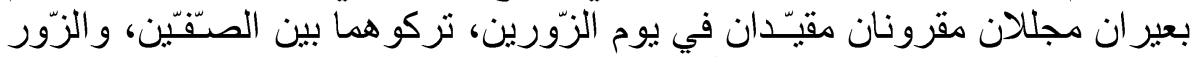

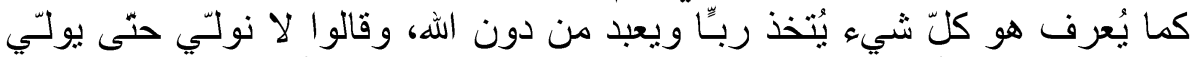

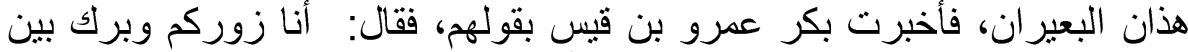

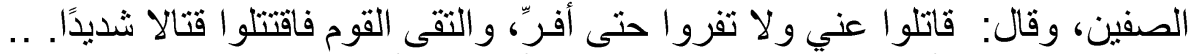

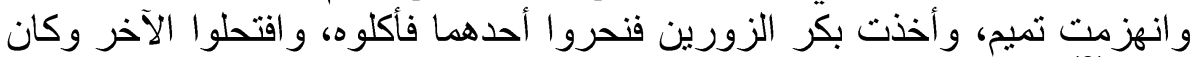

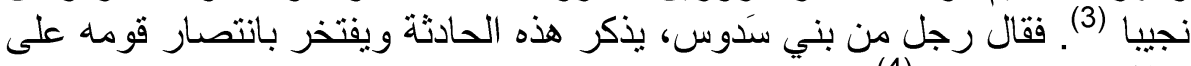
قبيلة تميم وزوريها (4).

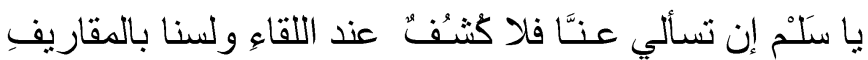
نحن الذين هَزَمَنْا يومَ صَبَّحنا جيشَ الزَّرِين في جَمع الأحاليفِ

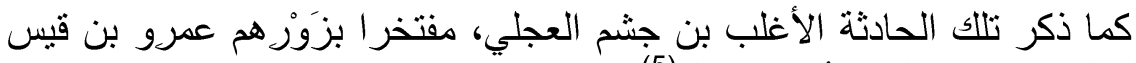

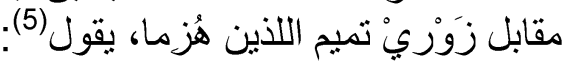

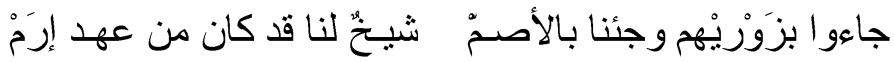

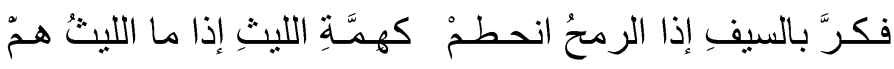

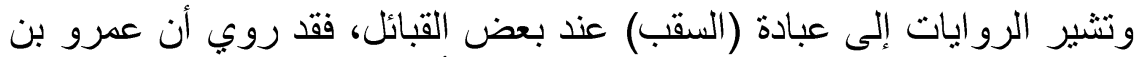

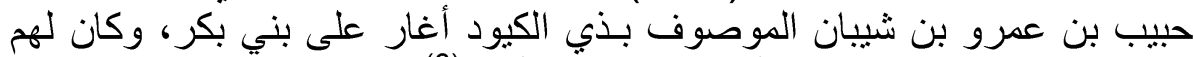

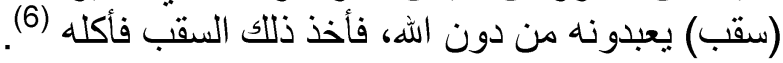
كما أن العرب عبدت الحجارة البيضاء اللون، وكل ما لها علافة بالإبل ولبنها (7). وتقول إحدى الروايات إن " الزباء " ناقة أبي دؤاد الإيادي، وهي ناقة ميمونة،

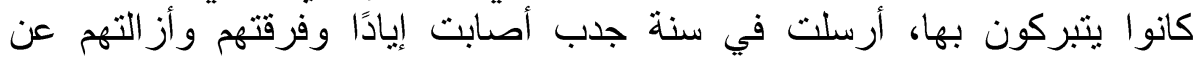

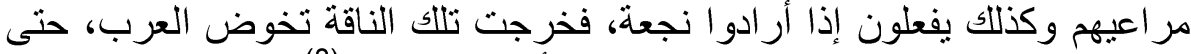

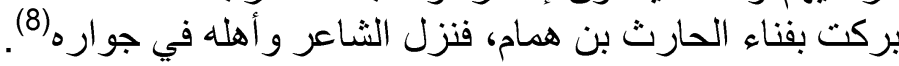

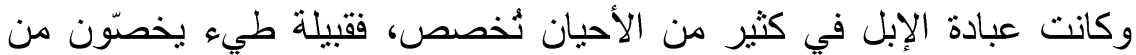

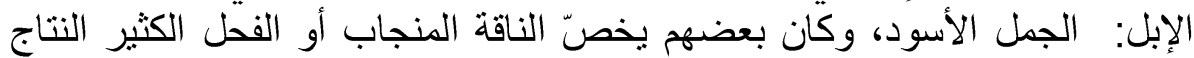

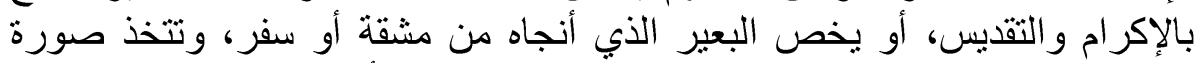

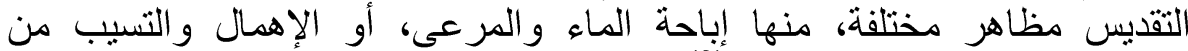

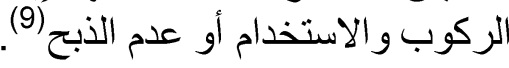

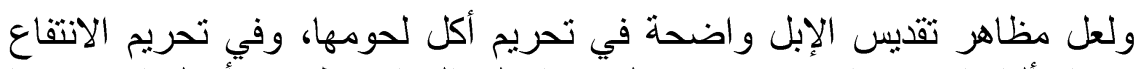

بظهور ها و ألبانها ووبرها، وقد يحرمون لحومها على النساء فقط. وقد أَدرك الإسلام ما 


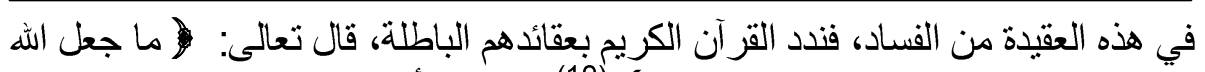

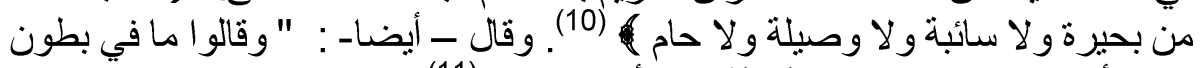

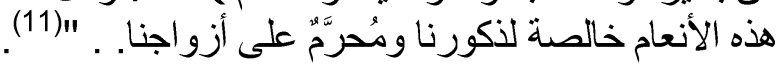

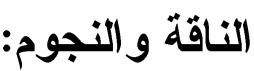

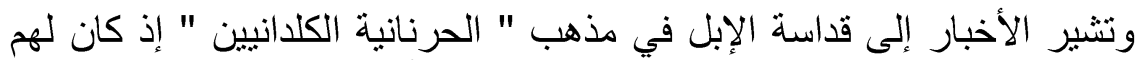

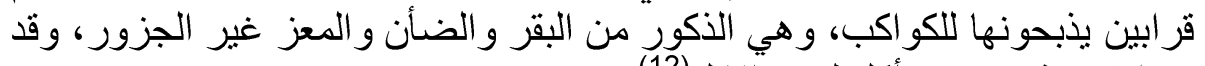

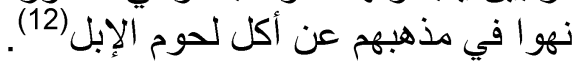

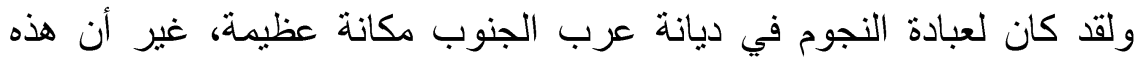

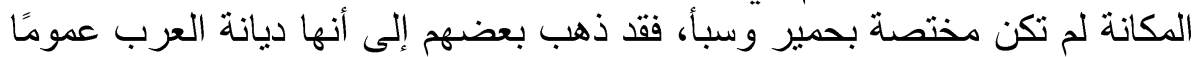

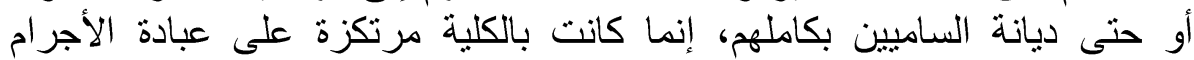

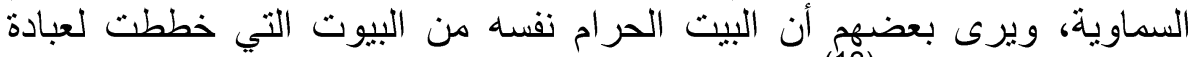
الكو اكب السيارة السبع (13) البعن

وعرف عرب الجاهلية الأولى عبادة الكواكب بالثكل الذبي نجده في ديانات

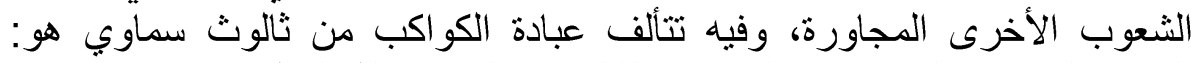

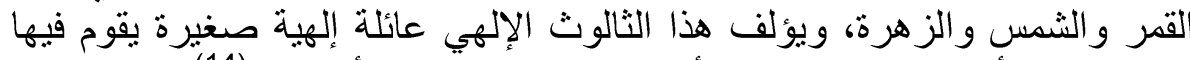
القمر بدور الأب، والثمس بدور الأم، والزهذ هرة بدور الإبن أو الابنة الفية (14).

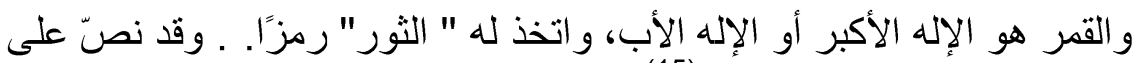
اسمه في الكتابات، إذ قيل لله: ثور الإكبر (15).

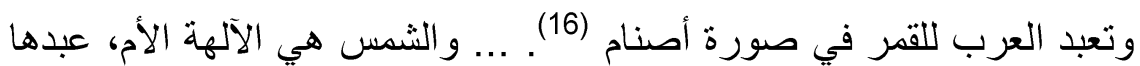

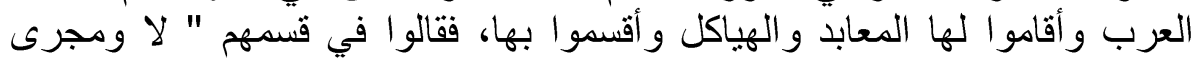

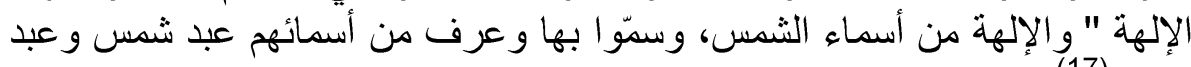
شارق (17) وكان للشمس عند العرب صنم، لقوم من عذرة."18).

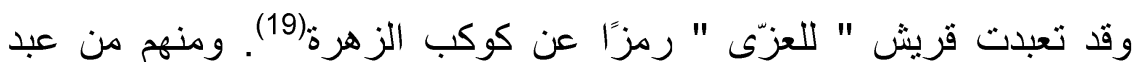

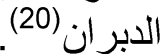

ورمز الجاهليون بالإبل عن نجوم كثبرة، فالناقة العنتريس التي وصفها الشعر اء لها مثال في السماء، وفي المجرّة بحيال السمكة المعدودة في المئرة المنازل، من ناحية

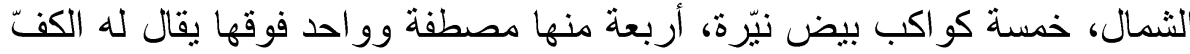
الخضيب. و هي كفّ الثريا المتوسطة. ويقال لها سنامُ الناقة، لأنها في خِلقة السيّام. و الناقة على خِلقة الناقة النجيبة الضامرة، الدقيقة العنق الصغيرة الر أس، و عنقهُ ولها 


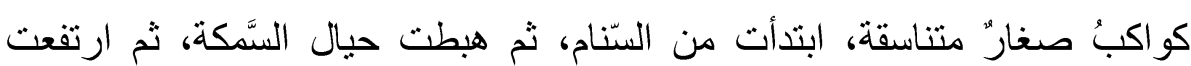

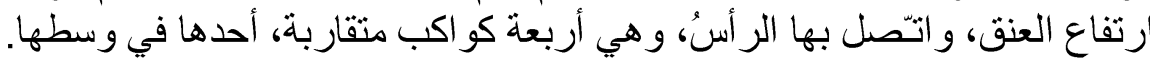

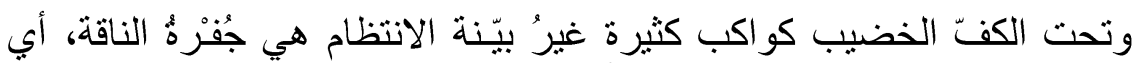

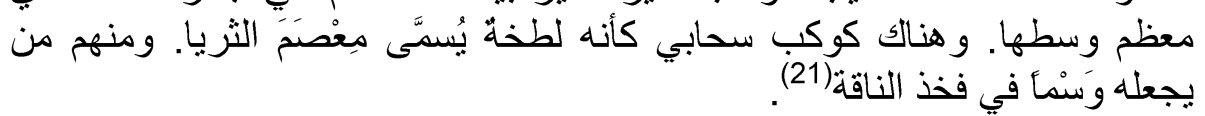
وقد تصور الجاهليون السماء مطيّة تشدّ عليها الطنافس تحت الرّحل، فقال أمية بن أبي الصلت (22):

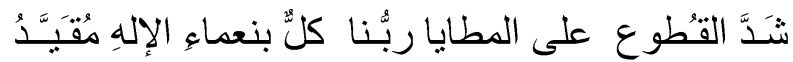

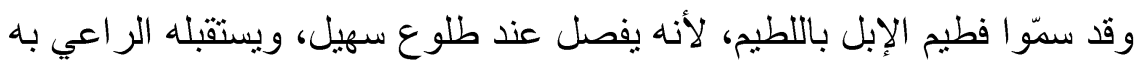

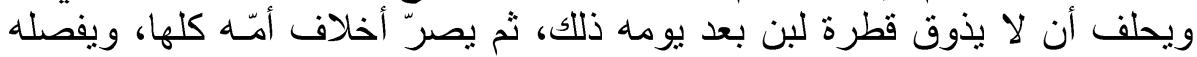

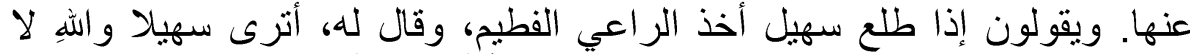

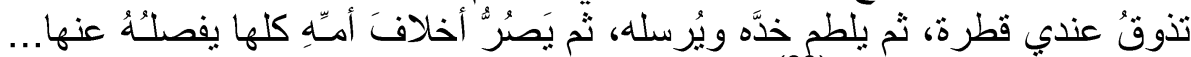

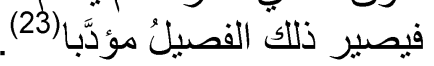

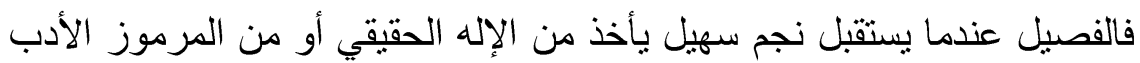

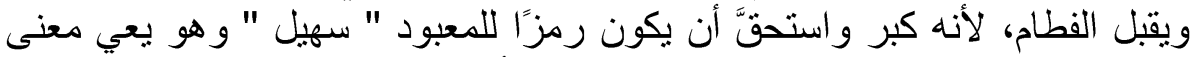

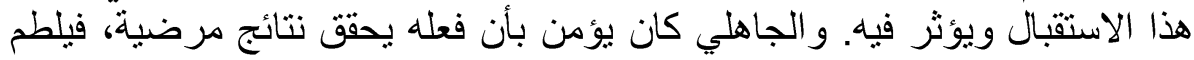

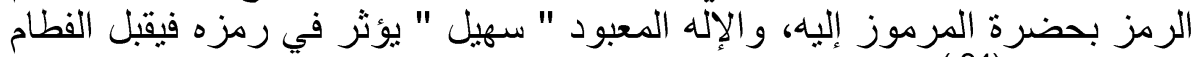
ويصبح مؤدَّبا(24 ).

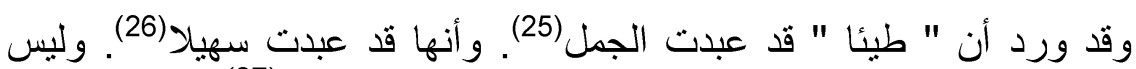

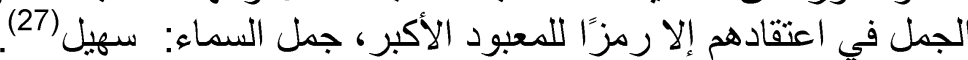

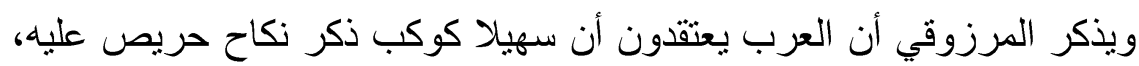

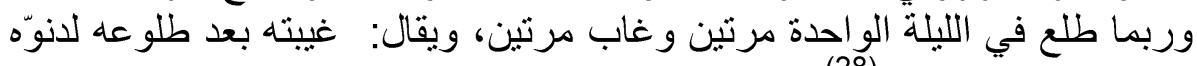
من كوكبتيه وصناحبنيه في (28) ويتكرر منظر " سهيل " في أحاديث الرحلة، كأنه النجم الساهر على سلامة الر احلين، يقول المتلمس الضبعي (29):

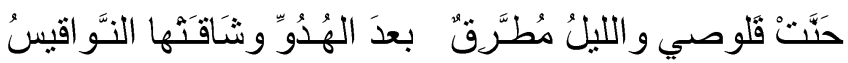

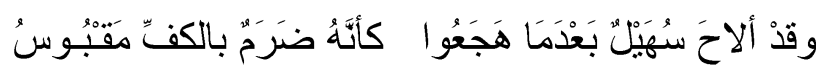
ويقول عبيد بن الأبرص(30):

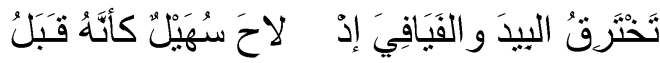


ويقول الثــَّهـَّاخ (31):

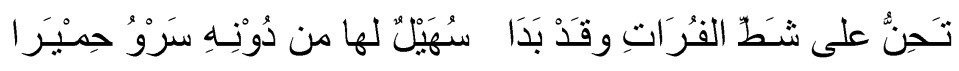

وون عادة بعض العرب ممن يعبدون " كوكب الصباح " في تقديم القرابين إليه

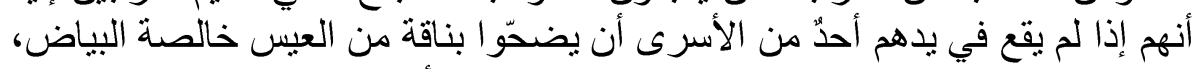

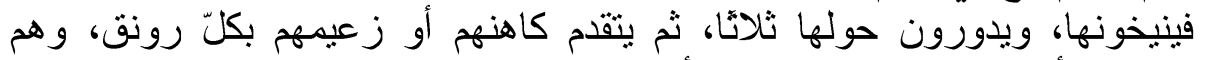

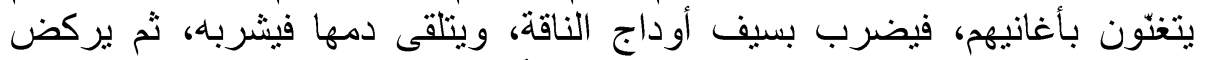

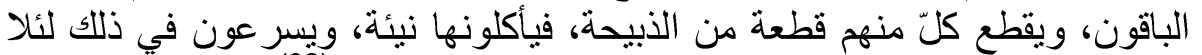

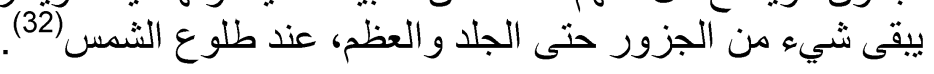

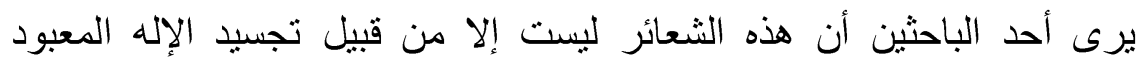

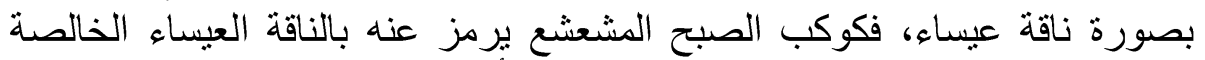

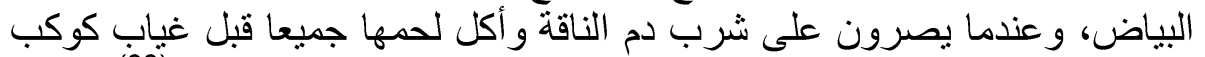

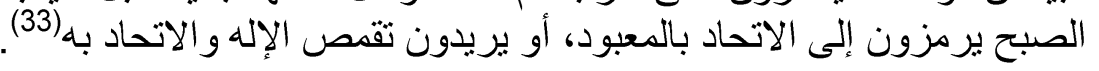

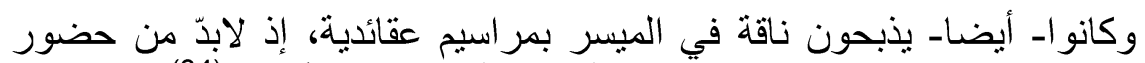

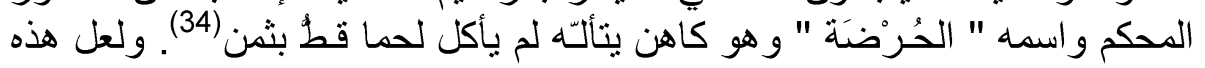

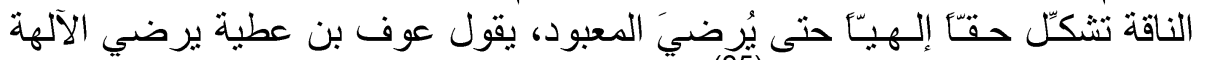
بزجر القداح في النوق السّـمان (35).

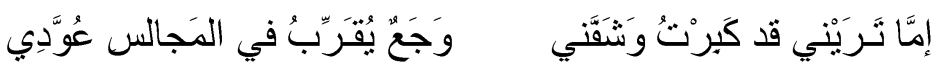

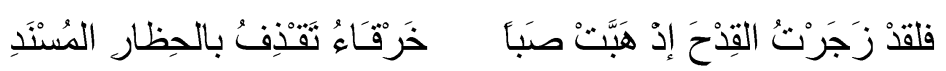

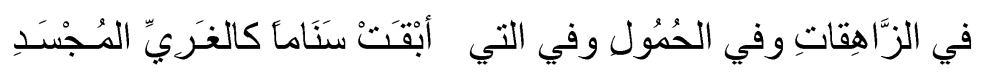

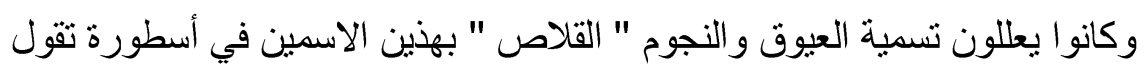

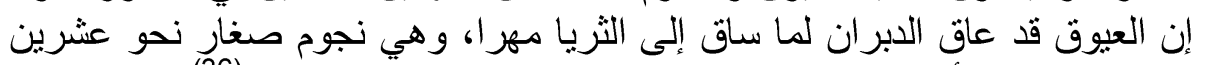

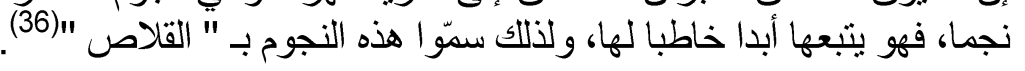

الناقة و المطر : نو

ومن خلال منظر الصحر اء المرعب، والحرارة المهلكة، نظر الإنسان الجاهلي

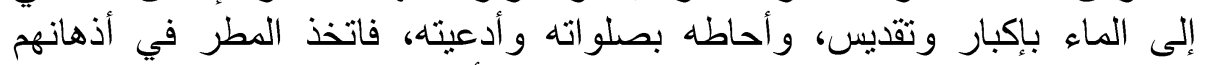

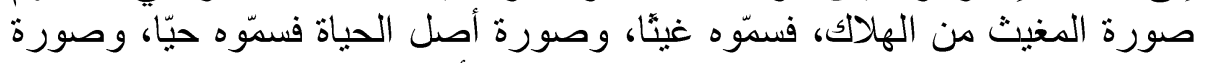

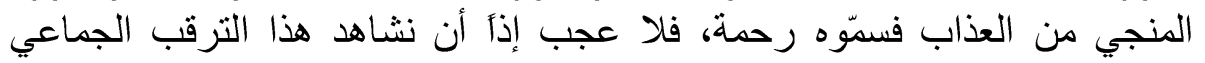

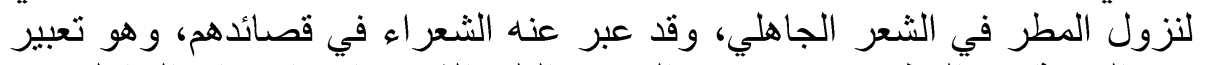

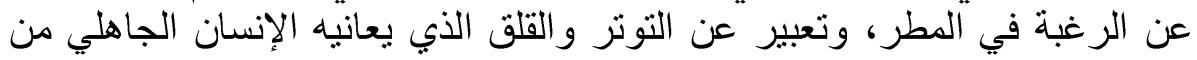

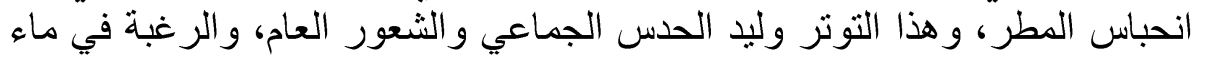




\section{حمود الدغيشى \\ الحياة(37).}

ويعبر الأعشى عن تلاك الرغبة، بقوله (38):

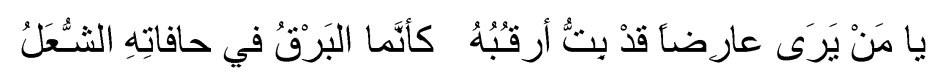

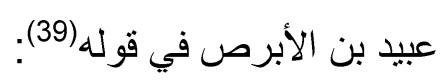

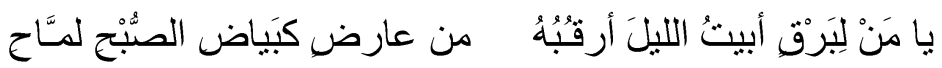

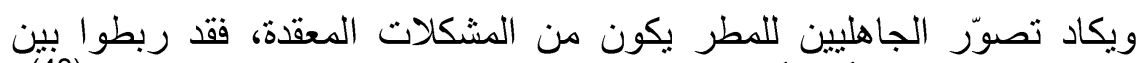

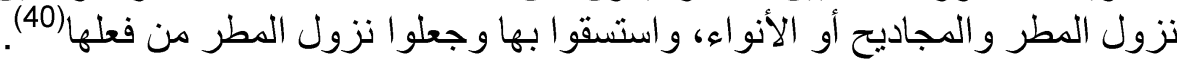

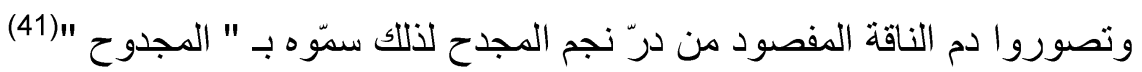

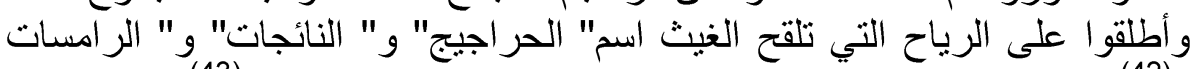

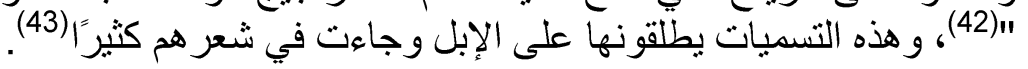

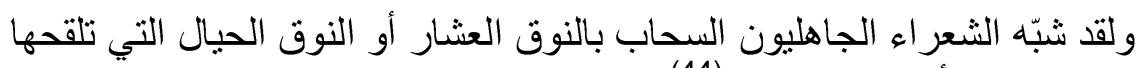

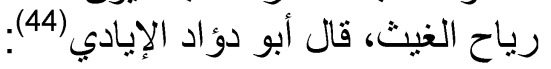

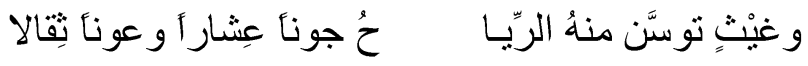

$$
\begin{aligned}
& \text { إذا كَرْكَرَتُهُ رياحُ الجنو }
\end{aligned}
$$

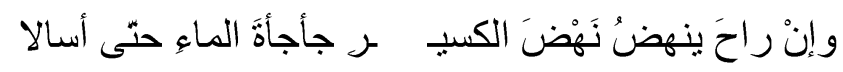

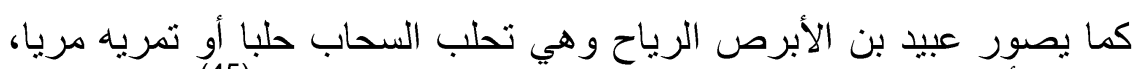

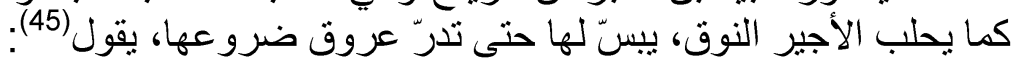

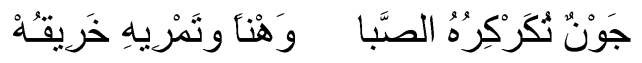

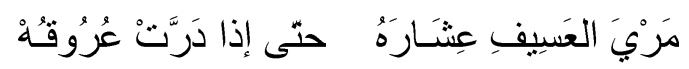

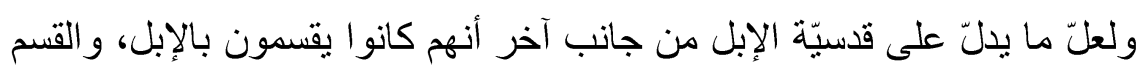

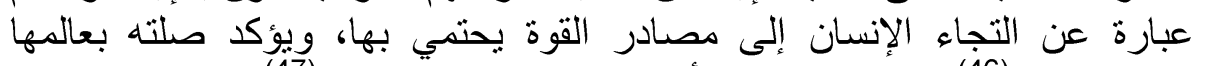

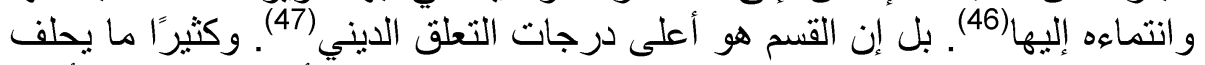

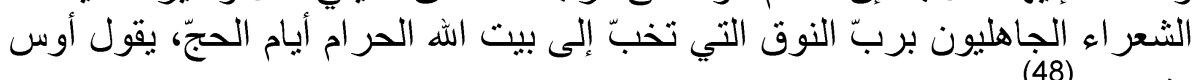

$$
\text { بن حجر (48): }
$$

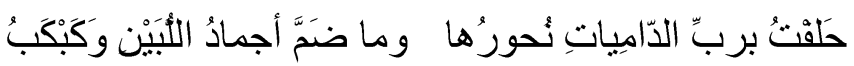

$$
\text { ويقول طرفة بن العبد (49): }
$$

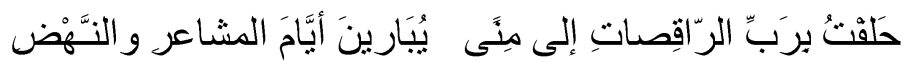




$$
\begin{aligned}
& \text { و النابغة الذبياني في فوله(50): }
\end{aligned}
$$

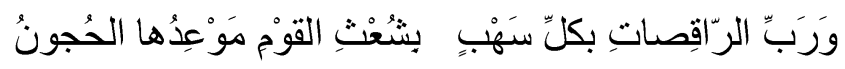

$$
\begin{aligned}
& \text { وبشر بن أبي خازم يحلف قائلا(51): }
\end{aligned}
$$

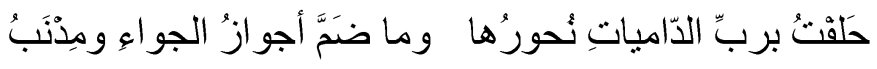

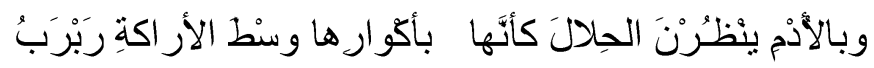

$$
\begin{aligned}
& \text { وكذلك الأعثى في قوله (52): }
\end{aligned}
$$

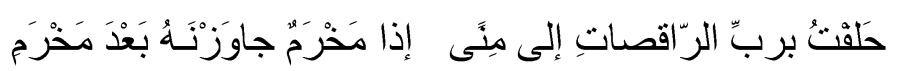

$$
\begin{aligned}
& \text { أساطير وطقوس عقدية: }
\end{aligned}
$$

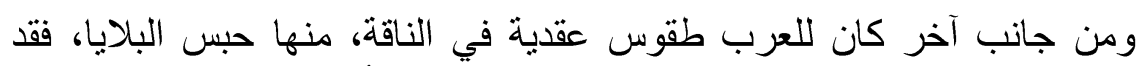

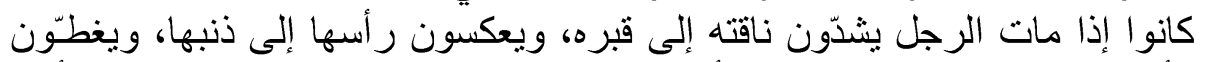

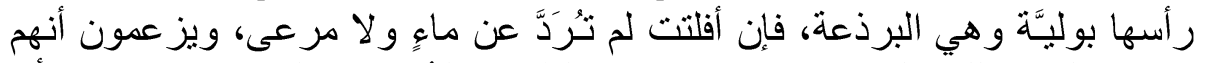

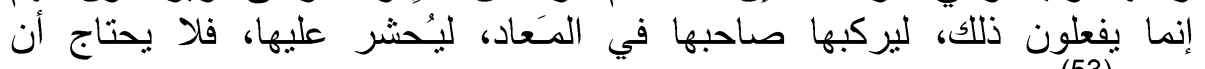
يمشي (53).

ويظهر هذا الطقس العقدي في شعر أبي زبيد الطائي، في قوله (54).

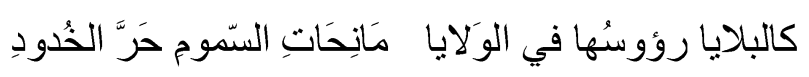

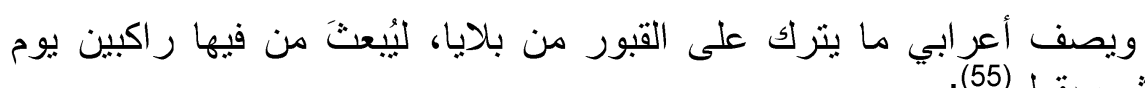

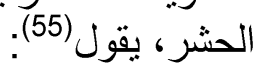

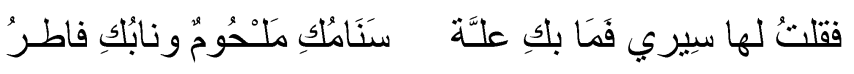

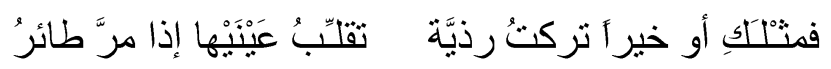

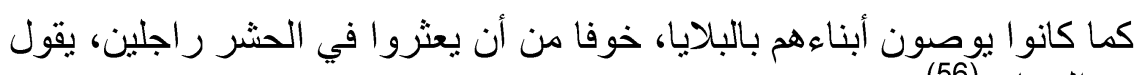
عويمر النبهاني (56):

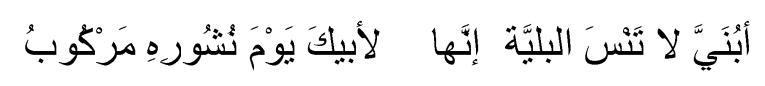

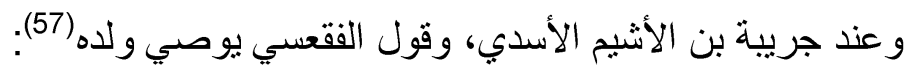

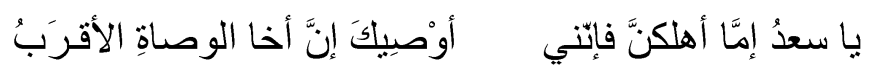

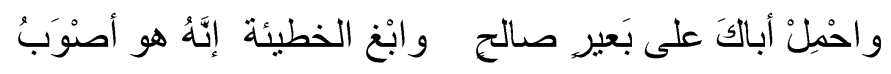

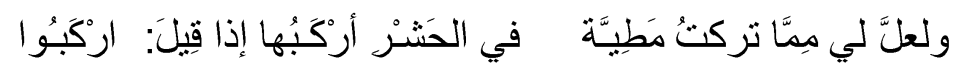


وشيّهّ مطرود بن كعب النائحات اللاتي ييكين بالبلايا (58):

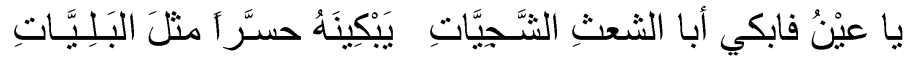

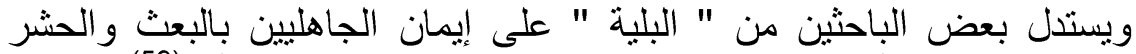
بالأجساد بعد الموت، أو هو مذهب من كان يقول منهم بالبعث وهم الأقل (59).

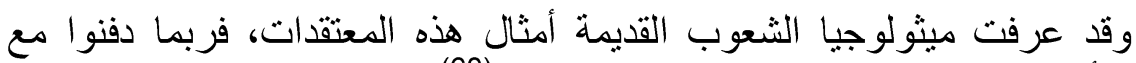

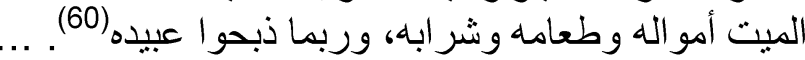

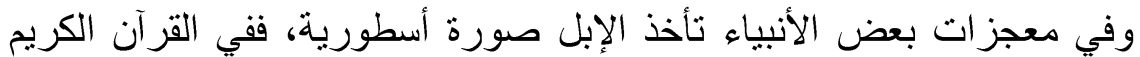

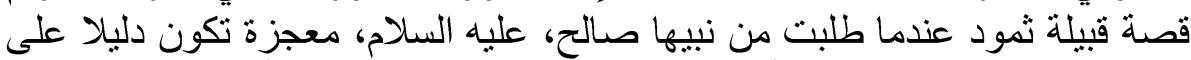

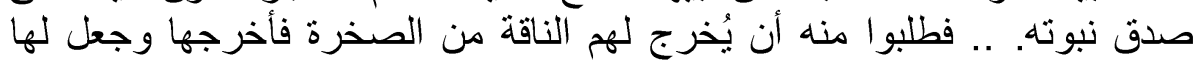

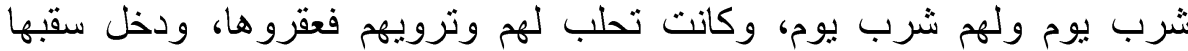

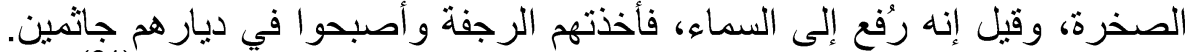

وقد ضربوا الثؤم بعاقر نلك الناقة، وجاء ذلك في شعر زهير بن بن أبي سلمى (61):

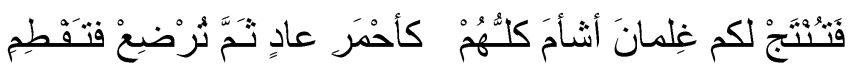

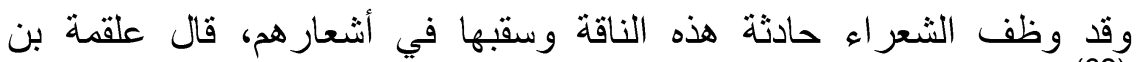

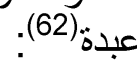

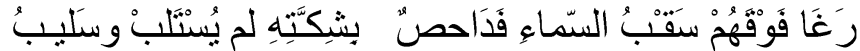

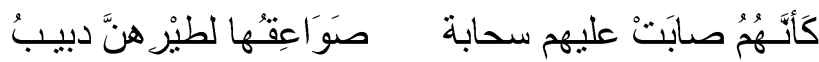

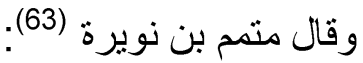

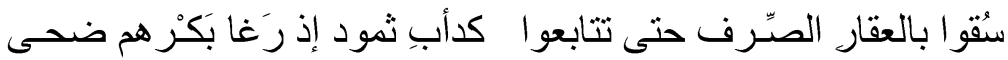
وقال أبو كبير الهذلي (64).

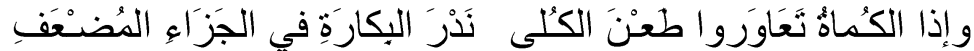

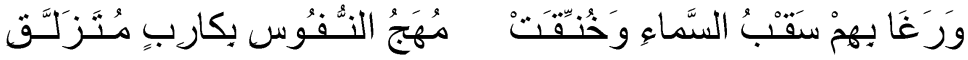
ويستلهم مالك بن خالد الخناعي لقضية الموت و الفناء في ساحة المعركة حادثة

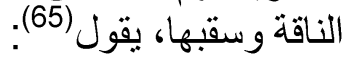

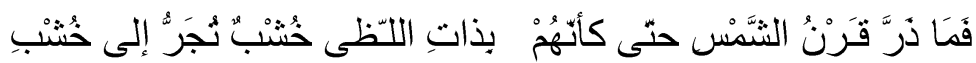

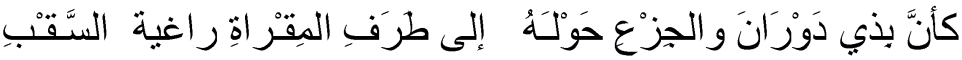
ولقد كان من مذاهب العرب في الإبل اعتقادهم أن أعطان الإبل خُلقت من أعنان 
الشياطين (66). وأن الحوش من الإبل التي قد ضربت فيها فحول إيل الجنّ. و الحوشيّة

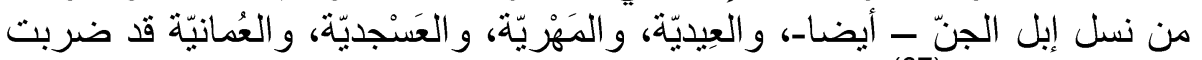
فيها الحوش كذلك (67).

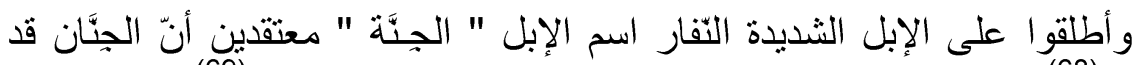

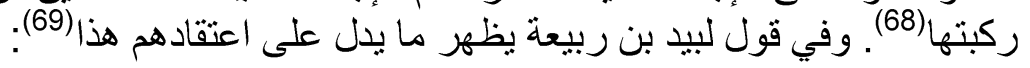

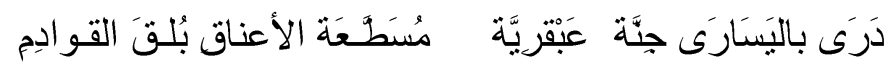

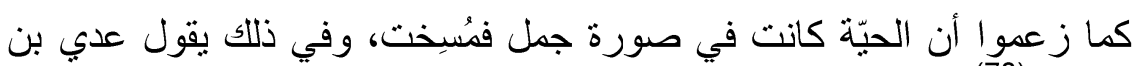
زيد العبادي (70): (كاري

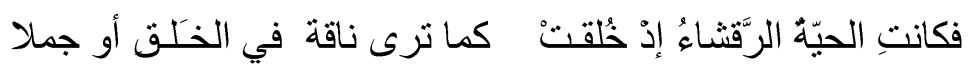

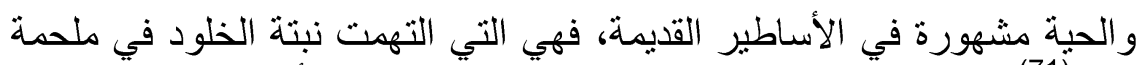

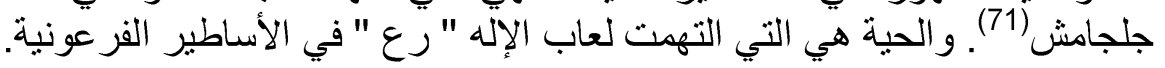

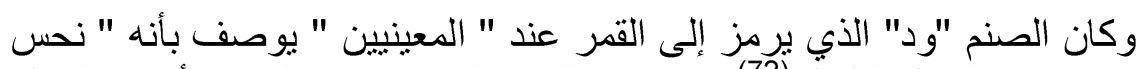

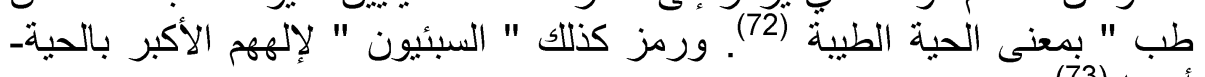
أيضا_(73)

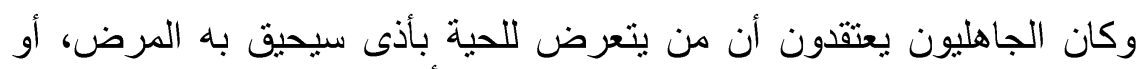

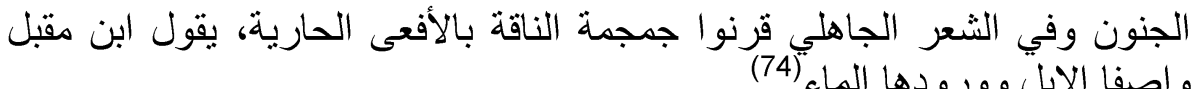

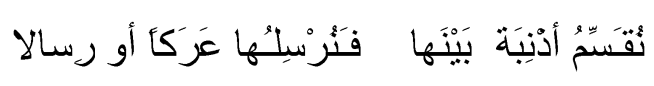

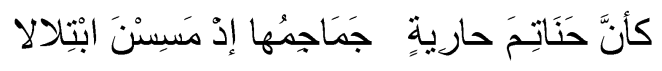

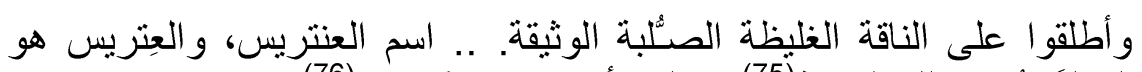

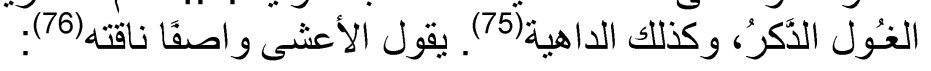

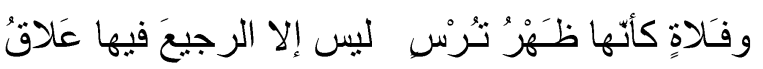

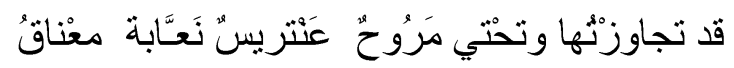

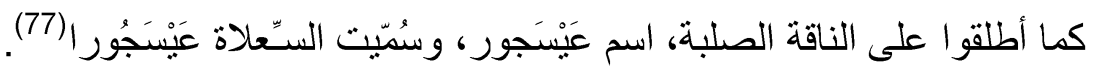

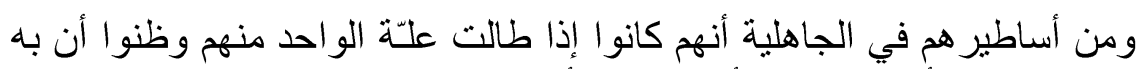

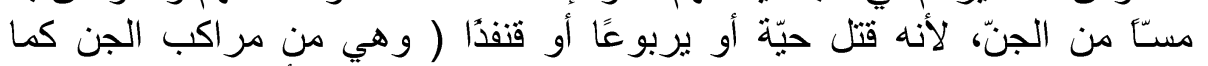

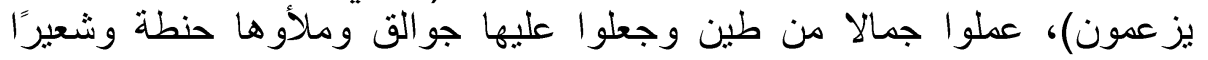

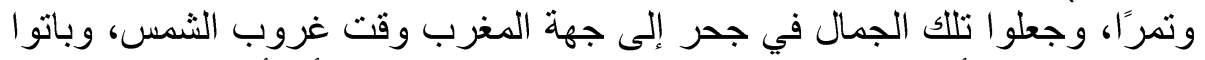
ليلتهم تللك، فإذا أصبحوا نظروا إلى تللك الجمال الطين، فإذا رأوا أنها بحالها فالو الثها لم 


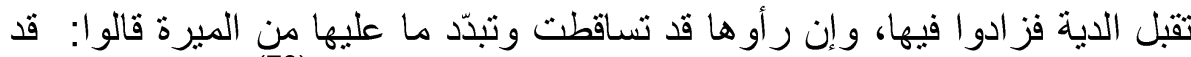

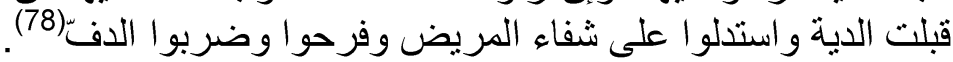

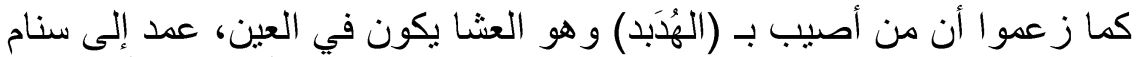

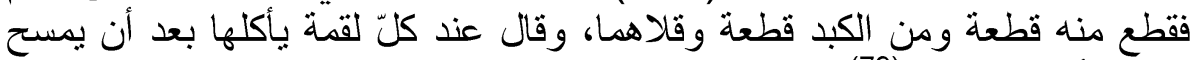
جفنه الأعلى بسبّـابته (79):

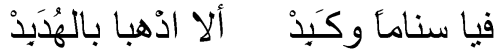

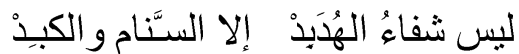

وفال آخر مؤكدًا على الفكرة نفسهاء(80):

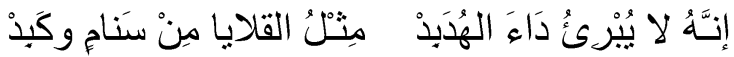

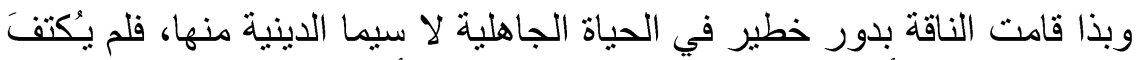
بها حيوانًا للركوب أو الطعام فحسب، بل دخلت في في أعمق القضايا الكونية وهي القاني قضية الدين و الإيمان، وشكلت بالنسبة للإنسان الجاهلي نافذة إيمانية ينظر من خلالها

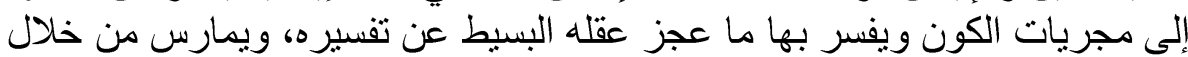

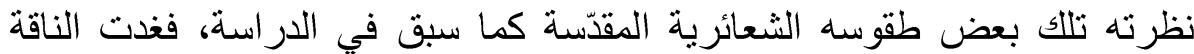

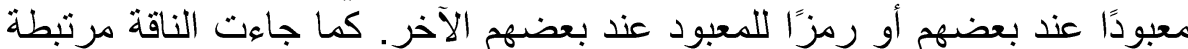
بالعنصر المقد للحياة في المجتمع الجاهلي وهو المطر الذي كان الذي يشكل عصب

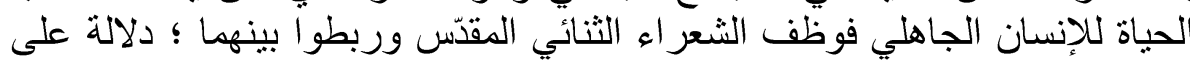

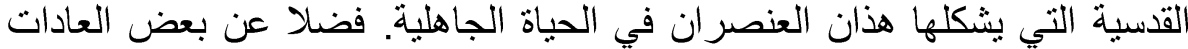

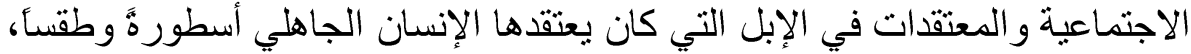

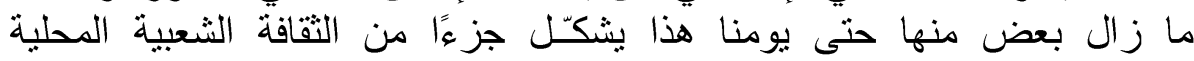
للمجتمعات البدوية الرعوية في مجتمعاتنا العربية.

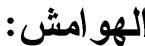

1- انظر : أنور أبو سويلم ، الإبل في الثنعر الجاهلي ، ص15 ، دار العلوم ، الرياض 1983م ـ سورة

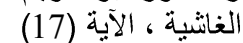

2- الأصفهاني ، أبو الفرج علي بن الحسين ( ت 356هـ / 967م ) : الأغاني ، شرح ، عبد علي مهنا وسمير

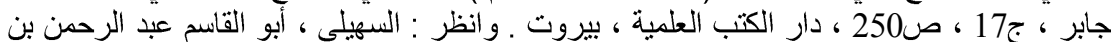

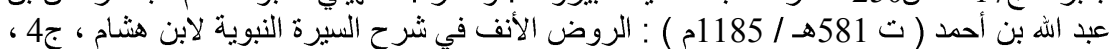

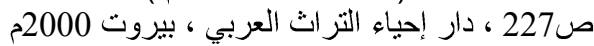


3 انظر القصة : ابن عبد ربه ، أحمد بن محمد ( 328هـ / 939م ) ) : العقد الفريد ، تحقيق أحمد أمين وآخرين

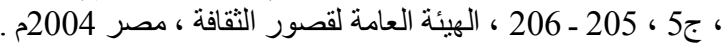

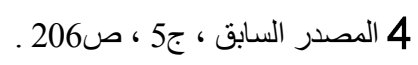$$
\text { 5 } 5 \text { نفسه ، ج5 ، ص206. }
$$

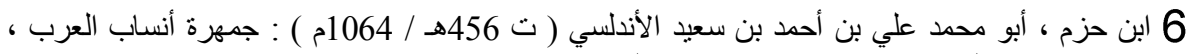

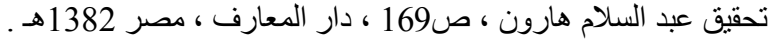

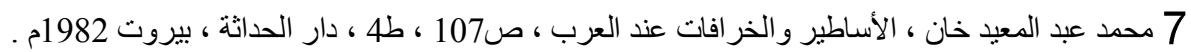

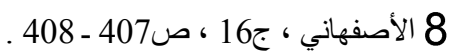

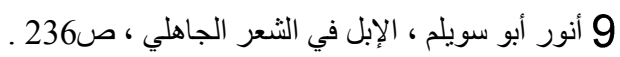

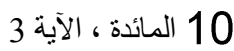

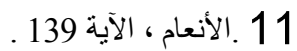

12 ابن النديم ، محمد بن إسحاق بن منذر ( ت 367هـ / 13971 ـ 977 م ) : الفهرست ، ص457 ، دار المعرفة ، بيروت 1997م.

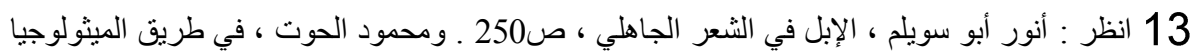

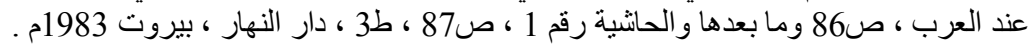

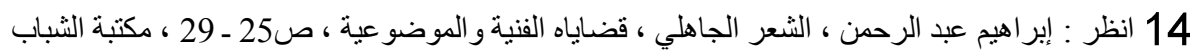

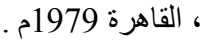

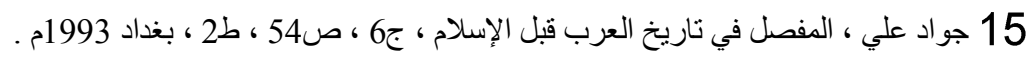

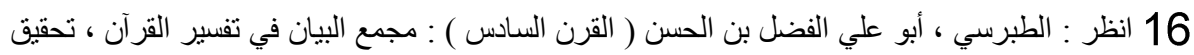

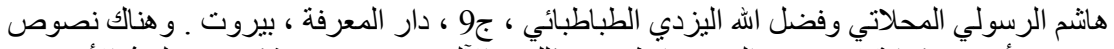

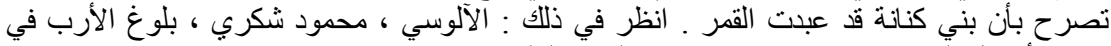

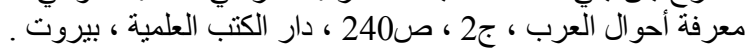

17 النجيرمي ، أبو إسحاق إبر اهيم بن عبداله بن محمد ( القرن الرابع ) : أيمان العرب في الجاهلية ، تحقيق ، بليق

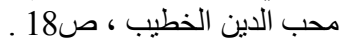

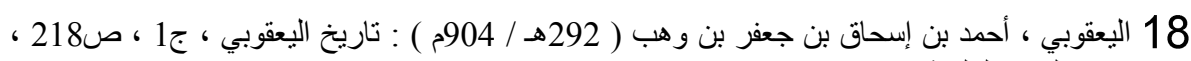
دار الكتب العلمية ، بيروت 2002م .

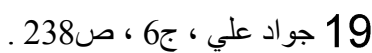

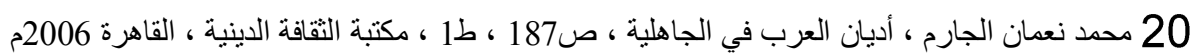

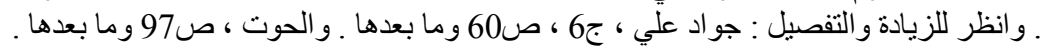

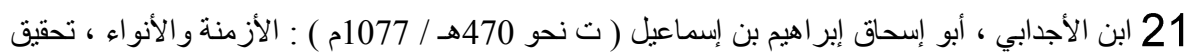

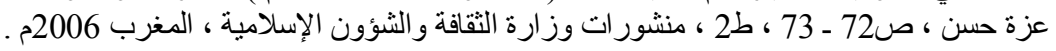




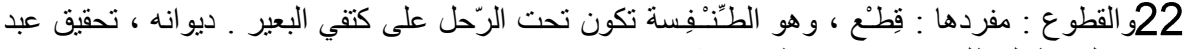

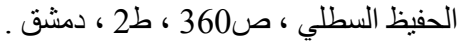

23 الزبيدي ، محمد مرتضى الحسيني (ت 1205 هـ / 1790م ) : تاج العروس ، مادة : لطم ، ج33 ، تحقيق ،

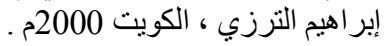

24 أنور أبو سويلم ، الإبل في الثعر الجاهلي ، ص257 ،

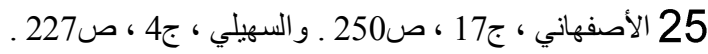

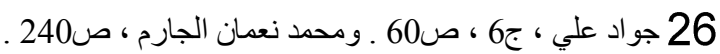

27 أنور أبو سويلم ، الإبل في الثعر الجاهلي ، ص257 هـ

28 المرزوقي ، أبو علي أحمد بن محمد بن الحسين ، (ت 421هـ / الائ 1030م ) : الأزمنة والأمكنة ، تحقيق

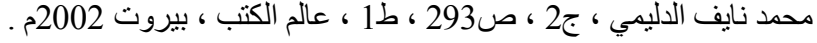

29 جرير بن عبد المسيح ، ديو انه ، تحقيق حسن كامل الصيرفي ، ص82 ، صدان.

30 ديو انه ، تحقيق حسين نصار ، ص96 ، صطبعة مصطفى البابي الحلبي ، القاهرة 1957م .

31 ديو انه ، تحقيق صلاح الدين الهادي ، ص1431 ، دار المعارف ، القاهرة .

32 لويس شيخو ، النصر انية وآدابها بين عرب الجاهلية ، ص16 ، ط2 ، دار المشرق ، بيروت 1989م ،

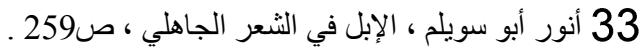

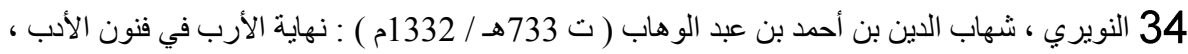

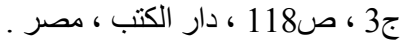

35 الأصمعي ، عبد الملك بن قريب ( ت 216هـ / 831م ) : الأصمعيات ، تحقيق أحمد شاكر وعبد السلام

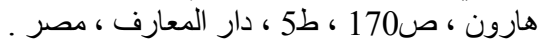

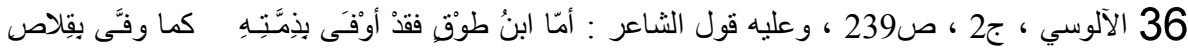

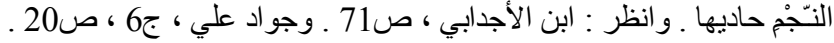

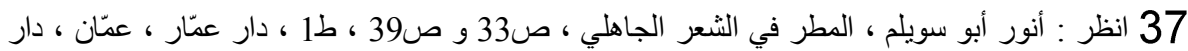

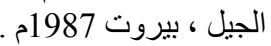

38 ميمون بن قبس ، ديو انه ، تحقيق محمد حسين ، ص57 ، م ، مكتبة الآداب ، مصر .

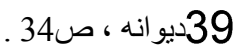

40 الزبيدي ، مادة : جدح ، ج6 ، تحقيق حسين نصار ، الكويت 1994م . وأنور أبو سويلم ، الإبل في

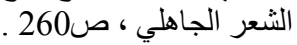

41 انظر : الزبيدي ، مادة : جدح ، ج6 ـ و أنور أبو سويلم ، الإبل في الثعر الجاهلي ، ص261 .

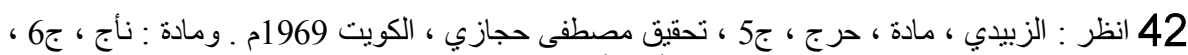

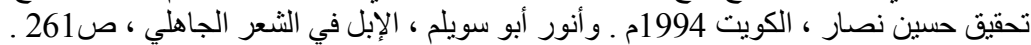


43 انظر : أنور أبو سويلم ، الإبل في الشعر الجاهلي ص261.

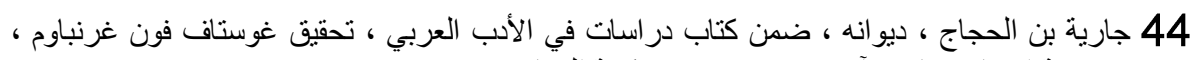

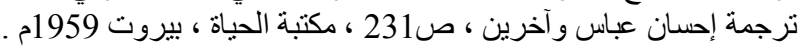

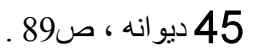

46 مصطفى ناصف ، قر اءة ثانية لثعرنا القديم ، ص87 47 ديونه ، دار الأندلس ، بيروت .

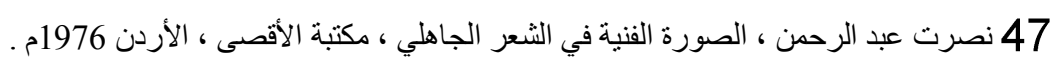

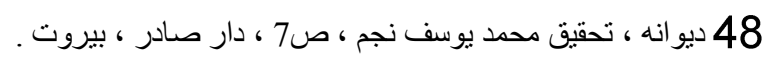

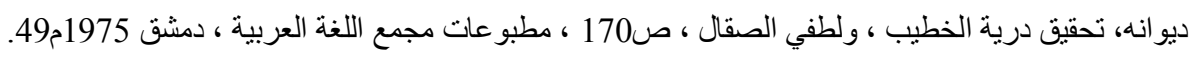

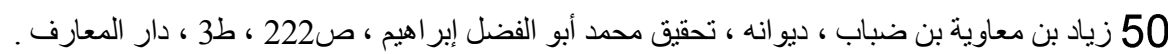

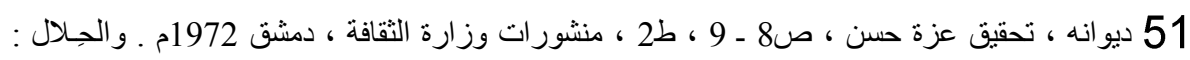

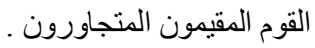

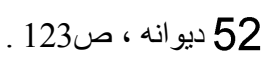

53 النويري ، ج3 ، ص121 ـ ـ وانظر : الثهرستاني : أبو الفتح محمد بن عبد الكريم (ت 548 54هـ / 153 1153م ) : الملل و النحل ، تحقيق محمد بن فريد ، ج2 ، ص232 ، كانئ ، المكتبة التوفيقية ، القاهرة .

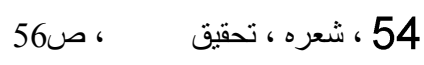

55 الجاحظ ، أبو عثمان عمرو بن بحر (ت 306 ، 255هـ / 868م ) : البيان والتبيين ، تحقيق عبد السلام هارون ،

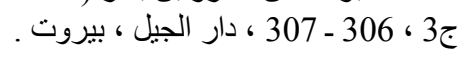

$$
56 \text { الآلوسي ، ج2 ، ص309 ، } 57 \text { ، } 506
$$

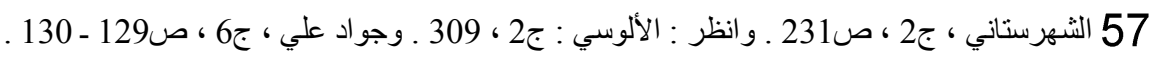

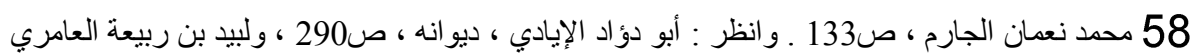

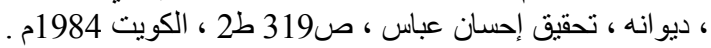

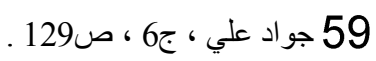

60 انظر تفاصيل ذلك: حمود الدغيشي، الخيل في الثعر الجاهلي، ص26 ، صو وما بعدها، ط1، دار جرير، عمّن 2007م.

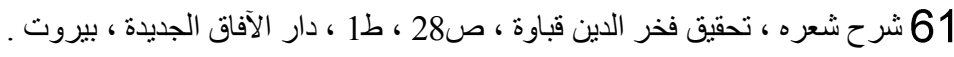

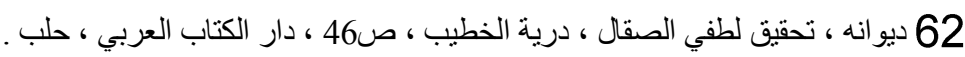

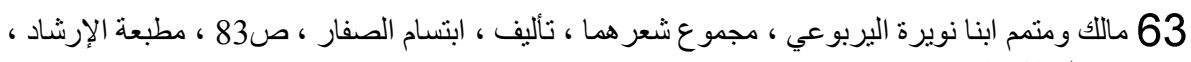

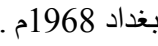

64 السكري ، أبو سعيد الحسن بن الحسين ( 275هـ / 888 888م ) ) : شرح أشعار الهذليين ، تحقيق عبد الستار احمد فراج ، ج3 ، ص1087 الحئ ـ 1088 ، دار العروبة القاهرة .

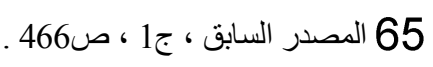


66 الجاحظ الحيو ان، تحقيق عبد السلام هارون، ج1، ص152، ط3، دار إحياء التزاث العربي، بيروت 1969م. 67 المصدر السابق ، ج6 ، ص216 68 أنور أبو سويلم ، الإبل في الثعر الجاهلي ، ص248 ، 69 70 ديو انه ، تحقيق محمد جبار المعيبد ، ص159 ، صدار ،دوار الجمهورية ، بغداد 1965م .

$$
\begin{aligned}
& 71 \text { جواد علي ، ج6 ، ص295 ديو ، }
\end{aligned}
$$

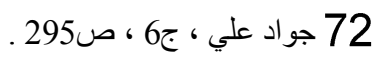

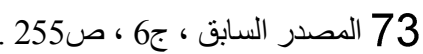

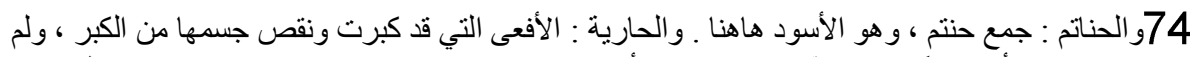

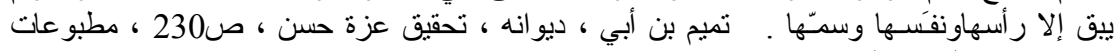

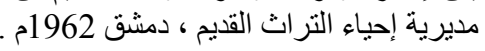

$$
\text { 75الزبيدي ، مادة : عترس ، ج16 ، تحقيق محمود الطناحي ، الكويت 2004م . }
$$

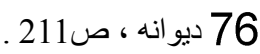

77 الزبيدي ، مادة : عسجر ، ج13 ، تحقيق محمود الطناحي ، الكويت 2004م .

$$
\text { 78 } 78 \text { الألوسي ، ج2 } 358 \text { ، } 350
$$

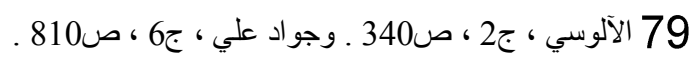

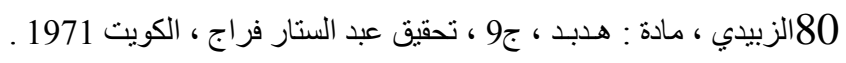

